\title{
Oxidation of styrene to benzaldehyde by $p$-toluenesulfonic acid using hydrogen peroxide in the presence of activated carbon
}

\author{
Nianzhe Li, Yuan Gao, Xinxin Zhang, Zhanjun Yu, Lei Shi, Qi Sun* \\ Institute of Chemistry for Functionalized Materials, Faculty of Chemistry and Chemical Engineering, Liaoning Normal University, Dalian 116029, Liaoning, \\ China
}

A R T I C L E I N F O

Article history:

Received 25 December 2014

Accepted 30 January 2015

Published 20 May 2015

\section{Keywords:}

Styrene

Hydrogen peroxide

$p$-Toluenesulfonic acid

Activated carbon

Oxidation

\begin{abstract}
A B S T R A C T
The selective oxidation of styrene to benzaldehyde catalyzed by $p$-toluenesulfonic acid ( $p$-TsOH) in the presence of activated carbon (AC) was investigated with $\mathrm{H}_{2} \mathrm{O}_{2}$ as the oxidant. The reaction parameters of reaction time, temperature, catalyst mass, and styrene $/ \mathrm{H}_{2} \mathrm{O}_{2}$ molar ratios were evaluated. A strong promoting effect of $\mathrm{AC}$ on the $p-\mathrm{TsOH} / \mathrm{H}_{2} \mathrm{O}_{2}$ system was observed. The appropriate ratio and amounts of $\mathrm{AC}$ and $p$-TsOH were an important factor. The acidity of $p$-TsOH does not play a significant role. $p$-TsOH reacted with $\mathrm{H}_{2} \mathrm{O}_{2}$ by a non-radical process to oxidize styrene. The function of the AC was to activate $\mathrm{H}_{2} \mathrm{O}_{2}$ and to help the $p$ - $\mathrm{TsOH} / \mathrm{H}_{2} \mathrm{O}_{2}$ system in styrene oxidation. The reduction of oxygen containing groups $(-\mathrm{OH},-\mathrm{COOH})$ on $\mathrm{AC}$ by a high temperature treatment or introduction of $-\mathrm{SO}_{3} \mathrm{H}$ groups onto $\mathrm{AC}$ affected the styrene conversion. The $-\mathrm{SO}_{3} \mathrm{H}$ groups were more effective than the oxygen-containing groups on the $\mathrm{AC}$ in promoting styrene oxidation.
\end{abstract}

(C) 2015, Dalian Institute of Chemical Physics, Chinese Academy of Sciences. Published by Elsevier B.V. All rights reserved.

\section{Introduction}

The selective oxidation of styrene to benzaldehyde can be carried out by using atmospheric oxygen [1,2], alkyl hydroperoxides [3,4], or $\mathrm{H}_{2} \mathrm{O}_{2}$ [5-9] in the presence of an appropriate metal-based catalyst to activate the oxidant. The use of $\mathrm{H}_{2} \mathrm{O}_{2}$ to oxidize styrene produces different products, depending upon the catalyst and the reaction conditions. $\mathrm{H}_{2} \mathrm{O}_{2}$ combined with a catalyst can provide hydroxyl radicals $(\cdot \mathrm{OH}) \cdot \cdot \mathrm{OH}$ can attack styrene by electrophilic addition to the multiple $\mathrm{C}-\mathrm{C}$ bonds and aromatic rings [10,11].

Recently, some carbon or silica supported sulfonic acid were prepared and used as a solid acid catalyst in many reactions [12-15]. Using $\mathrm{H}_{2} \mathrm{O}_{2}$ as an oxidant, the solid acid catalysts (supported sulfonic acid) as a metal-free catalyst selectively oxidized organic compounds. For example, Maggi et al. [12] developed silica- and polystyrene-supported sulfonic acids as a metal-free heterogeneous catalyst for the oxidation of hydroquinones to the corresponding 1,4-benzoquinones with $\mathrm{H}_{2} \mathrm{O}_{2}$. Yang et al. [16] investigated sulfonated carbon as a catalyst for the oxidation of aldehydes to the corresponding acids by $\mathrm{H}_{2} \mathrm{O}_{2}$. Sato et al. [17] reported a procedure for the synthesis of 1,2-diols by the dihydroxylation of olefins with $\mathrm{H}_{2} \mathrm{O}_{2}$ catalyzed by resin-supported sulfonic acid.

$p$-Toluenesulfonic acid ( $p$ - $\mathrm{TsOH})$ as a catalyst has shown successful results in some acid-catalyzed reactions [18-21]. $p$-TsOH contains a sulfonic acid group $\left(-\mathrm{SO}_{3} \mathrm{H}\right)$, and dissolves easily in water and is insoluble in organic reagents such as benzene, toluene, and alkanes. Thus, $p$-TsOH can be recycled by separating the organic phase and aqueous phase. Very recently, Rostami et al. [22] researched the selective oxidation of sulfides to sulfoxides using $\mathrm{H}_{2} \mathrm{O}_{2}$ catalyzed by $p$-TsOH under solvent-free conditions.

In order to extend the method of the selective oxidation of

\footnotetext{
* Corresponding author. Tel: +86-411-82159069; Fax: +86-411-82156858; E-mail: sunqils@163.com This work was supported by the National Natural Science Foundation of China (21173110). DOI: 10.1016/S1872-2067(14)60314-4 | http://www.sciencedirect.com/science/journal/18722067 | Chin. J. Catal., Vol. 36, No. 5, May 2015
} 
styrene, we evaluated the activity of $p$-TsOH as a metal-free catalyst for the oxidation of styrene to benzaldehyde with $\mathrm{H}_{2} \mathrm{O}_{2}$ as oxidant in the presence of activated carbon (AC). A strong promoting effect of $\mathrm{AC}$ on the $p-\mathrm{TsOH} / \mathrm{H}_{2} \mathrm{O}_{2}$ system was observed. Investigating the interaction of $p$ - TsOH and $\mathrm{AC}$ in the oxidation reaction will be helpful for understanding the reaction mechanism of solid acid catalysts in similar reaction systems.

\section{Experimental}

\subsection{Chemicals}

All chemicals used for the experiments were AR grade, including $\mathrm{AC}, \mathrm{HNO}_{3}$ (65\%), $\mathrm{H}_{2} \mathrm{SO}_{4}$ (98\%), and $p$-TsOH. These were obtained from Tianjin Kermel Chemical Reagents Company. Styrene (AR) and $\mathrm{H}_{2} \mathrm{O}_{2}(30 \%)$ were supplied by Sinopharm Chemical Reagents Company.

\subsection{AC pretreatment}

Commercial AC was first boiled in deionized water for $2 \mathrm{~h}$, and then washed with deionized water. The washed AC was treated with $65 \% \mathrm{HNO}_{3}$ at room temperature for $24 \mathrm{~h}$. After filtration, the acid-treated AC was washed thoroughly by deionized water and then dried at $105{ }^{\circ} \mathrm{C}$ overnight, and labeled as HAC. HAC was treated in a $\mathrm{N}_{2}$ or $5 \% \mathrm{H}_{2} / \mathrm{Ar}$ atmosphere by heating at a rate of $10{ }^{\circ} \mathrm{C} / \mathrm{min}$ to $800^{\circ} \mathrm{C}$, and then kept at this temperature for $6 \mathrm{~h}$. The samples are denoted as $\mathrm{HAC}_{\mathrm{N} 2}$ and $\mathrm{HACH}_{2}$.

In addition, HAC ( $1 \mathrm{~g}$ ) was heated in $100 \mathrm{~mL}$ concentrated $\mathrm{H}_{2} \mathrm{SO}_{4}(98 \%)$ at $150{ }^{\circ} \mathrm{C}$ for $15 \mathrm{~h}$ under $\mathrm{N}_{2}$ atmosphere. The resulting carbon material was washed with hot distilled water (> $80{ }^{\circ} \mathrm{C}$ ) until no sulfate ions were detected in the wash water. The resulting material was designated as $\mathrm{HAC}-\mathrm{SO}_{3} \mathrm{H}$. The $\mathrm{S}$ content of the sample was $5.5 \mathrm{mmol} / \mathrm{g}$, which was determined by X-ray fluorescence (Siements SRS3400).

\subsection{AC characterization}

X-ray diffraction (XRD) analysis was performed on a Rigaku D8 Advance diffractometer with $\mathrm{Cu} K_{\alpha}$ radiation, voltage $40 \mathrm{kV}$ and current $40 \mathrm{~mA}$. Fourier transform infrared (FT-IR) spectra were recorded in the range of $400-4000 \mathrm{~cm}^{-1}$ on a Bruker Tensor 27 spectrometer. The total acid content of the AC was obtained using a standard acid-base titration [23]. For a typical titration experiment, an AC sample mass of $0.5 \mathrm{~g}$ was suspended in $25 \mathrm{~mL}$ standard $\mathrm{NaOH}$ solution ( $0.1 \mathrm{~mol} / \mathrm{L})$ and shaken in a closed container for $24 \mathrm{~h}$. The slurry was filtered to remove AC. An aliquot of $10 \mathrm{~mL}$ was back-titrated with $0.1 \mathrm{~mol} / \mathrm{L} \mathrm{HCl}$.

\subsection{Styrene oxidation}

The oxidation experiments were carried out in a 50-mL glass reactor with magnetic stirring immersed in a water recirculating bath and equipped with a reflux condenser. A standard run is as follows: an amount of HAC or $p$-TsOH, $5 \mathrm{~mL}$ of acetonitrile, and styrene and $\mathrm{H}_{2} \mathrm{O}_{2}$ in proportion were added to the reactor and stirred by a magnetic stirrer at the set temperature for a set time. After the reaction, the products were analyzed using an Agilent-6890 gas chromatograph equipped with a FID using a HP-5 capillary column $(30 \mathrm{~m} \times 0.32 \mathrm{~mm} \times$ $0.25 \mu \mathrm{m}$ ) and $\mathrm{N}_{2}$ as the carrier gas. The internal standard method was adopted for the quantitative analysis of the products using toluene as an internal standard substance. The conversion of styrene ( $\left.C_{\text {styrene }}\right)$ and selectivity for benzaldehyde ( $S_{\text {benzaldehyde }}$ ) was defined as follows: $C_{\text {styrene }}=\left(n_{0}-n_{\text {styrene }}\right) / n_{0} \times$ $100 \% ; S_{\text {benzaldehyde }}=n_{\text {benzaldehyde }} /\left(n_{0}-n_{\text {styrene }}\right) \times 100 \% . n_{0}$ and $n_{\text {styrene denoted the initial mole number and the final mole }}$ number.

\section{Results and discussion}

\subsection{Reaction conditions}

We used $p$-TsOH as the catalyst for the selective oxidation of styrene to benzaldehyde with $\mathrm{H}_{2} \mathrm{O}_{2}$ as an oxidant in the presence of AC. In the preliminary study without styrene, no benzaldehyde was formed using either the $p-\mathrm{TsOH} / \mathrm{H}_{2} \mathrm{O}_{2}$ or the $p$-TsOH/HAC $/ \mathrm{H}_{2} \mathrm{O}_{2}$ system. The reaction parameters were first optimized for the oxidation of styrene. The results are summarized in Table 1. With $0.058 \mathrm{mmol}$ of $p$-TsOH as catalyst and 3.5 molar ratio of $\mathrm{H}_{2} \mathrm{O}_{2}$ /styrene at $60{ }^{\circ} \mathrm{C}$, the styrene conversion was very low, $8.7 \%$ after $5 \mathrm{~h}$ of reaction (Table 1, entry1). The low activity was attributable to $\mathrm{H}_{2} \mathrm{O}_{2}$ protonation to form an oxonium ion in the presence of $p$-TsOH $[22,24]$,

$$
\begin{aligned}
& p \text { - } \mathrm{TsOH} \rightarrow \mathrm{H}^{+}+p \text {-TsO } \\
& \mathrm{H}^{+}+\mathrm{H}_{2} \mathrm{O}_{2} \rightarrow \mathrm{H}_{3} \mathrm{O}_{2}{ }^{+}
\end{aligned}
$$

which enhanced $\mathrm{H}_{2} \mathrm{O}_{2}$ stability and reduce its reactivity. When AC treated by $\mathrm{HNO}_{3}$ (HAC) was added into the $p$ - $\mathrm{TsOH} / \mathrm{H}_{2} \mathrm{O}_{2}$ system, the styrene conversion increased. For example, the styrene conversion and benzaldehyde selectivity were $35.3 \%$ and $85.4 \%$, respectively, when 10 mg HAC was added, and they were $43.3 \%$ and $86.8 \%$, respectively, when adding $50 \mathrm{mg} \mathrm{HAC}$ (Table 1, entries 2 and 3). The results showed that the addition

\section{Table 1}

Oxidation of styrene to benzaldehyde with $\mathrm{H}_{2} \mathrm{O}_{2}$ catalyzed by $\mathrm{HAC}$ and $p$-TsOH under different conditions.

\begin{tabular}{lrccccc}
\hline Entry & $\begin{array}{r}\mathrm{HAC} \\
(\mathrm{mg})\end{array}$ & $\begin{array}{c}p \text {-TsOH } \\
(\mathrm{mmol})\end{array}$ & $\begin{array}{c}\mathrm{H}_{2} \mathrm{O}_{2} / \text { styrene } \\
(\mathrm{mol} / \mathrm{mol})\end{array}$ & $\begin{array}{c}\text { Temperature } \\
\left({ }^{\circ} \mathrm{C}\right)\end{array}$ & $\begin{array}{c}C_{\text {styrene }} \\
(\%)\end{array}$ & $\begin{array}{c}S_{\text {benzaldehyde }} \\
(\%)\end{array}$ \\
\hline 1 & 0 & 0.058 & 3.5 & 60 & 8.7 & 90.1 \\
2 & 10 & 0.058 & 3.5 & 60 & 35.3 & 85.4 \\
3 & 50 & 0.058 & 3.5 & 60 & 43.3 & 86.8 \\
4 & 10 & 0 & 3.5 & 60 & 3.0 & 90.3 \\
5 & 10 & 0.29 & 3.5 & 60 & 53.5 & 81.5 \\
6 & 50 & 0.29 & 3.5 & 60 & 80.1 & 86.5 \\
7 & 100 & 0.58 & 3.5 & 60 & $>99$ & 53.2 \\
8 & 10 & 0.058 & 3.5 & 40 & 13.6 & 87.0 \\
9 & 10 & 0.058 & 3.5 & 50 & 21.2 & 86.3 \\
10 & 10 & 0.058 & 3.5 & 80 & 68.2 & 71.7 \\
11 & 10 & 0.058 & 2.5 & 60 & 14.1 & 89.2 \\
12 & 10 & 0.058 & 4.0 & 60 & 35.8 & 83.0 \\
13 & 10 & 0.058 & 4.5 & 60 & 37.0 & 80.1 \\
$14 *$ & 10 & 0.058 & 4.5 & 60 & 38.3 & 82.0 \\
\hline
\end{tabular}

Reaction conditions: styrene $5 \mathrm{mmol}$, acetonitrile $5 \mathrm{~mL}, 5 \mathrm{~h}$

* Using recycling HAC. 
of HAC into the $p$-TsOH/ $/ \mathrm{H}_{2} \mathrm{O}_{2}$ system increased the styrene conversion.

Carbon as a catalyst has been used in several processes for the oxidation of organic compounds in liquid using $\mathrm{H}_{2} \mathrm{O}_{2}$ as the oxidant [25-27]. When using only $10 \mathrm{mg}$ HAC as catalyst, the conversion of styrene was very low, and was $3 \%$ after $5 \mathrm{~h}$ of reaction (Table 1 , entry 4 ).

It is generally thought that the interaction of $\mathrm{AC}$ with $\mathrm{H}_{2} \mathrm{O}_{2}$ generates free radical species $(\cdot 0 \mathrm{H} / \cdot \mathrm{OOH})$ according to the following reaction, Eqs. (3) and (4) [11,27,28].

$$
\begin{aligned}
& \mathrm{AC}+\mathrm{H}_{2} \mathrm{O}_{2} \rightarrow \mathrm{AC}+\mathrm{OH}^{-}+\cdot \cdot \mathrm{OH} \\
& \mathrm{AC}^{+}+\mathrm{H}_{2} \mathrm{O}_{2} \rightarrow \mathrm{AC}+\mathrm{H}^{+}+\cdot{ }^{\cdot} \mathrm{OOH}
\end{aligned}
$$

The free radical species directly oxidize styrene to form the oxidation products.

It is important to note that when using HAC as catalyst, some $\mathrm{O}_{2}$ was formed by $\mathrm{H}_{2} \mathrm{O}_{2}$ decomposition in the solution of styrene, acetonitrile, $\mathrm{H}_{2} \mathrm{O}_{2}$, and $\mathrm{HAC}$ (Fig. 4). The formation of $\mathrm{O}_{2}$ was attributed to the interaction between the free radical species according to the reaction Eq. (5) [11,12,29].

$$
\cdot \mathrm{OH}+\cdot \cdot \mathrm{OOH} \rightarrow \mathrm{H}_{2} \mathrm{O}+\mathrm{O}_{2}
$$

Thus, the low activity over HAC implied that the reaction between the free radical species and styrene was the rate determining step. The faster reaction between the free radicals generates more $\mathrm{O}_{2}$, while part of the $\mathrm{H}_{2} \mathrm{O}_{2}$ was consumed.

When the amount of HAC was fixed (10 mg), and the amount of $p$-TsOH was increased from 0.058 to $0.29 \mathrm{mmol}$, after $5 \mathrm{~h}$ of reaction, the corresponding styrene conversion increased from $35.3 \%$ to $53.5 \%$ while the benzaldehyde selectivity only decreased from $85.4 \%$ to $81.5 \%$. When simultaneously increasing the amounts of both HAC and $p$-TsOH to $50 \mathrm{mg}$ and $0.29 \mathrm{mmol}$, respectively, a significantly promotion of styrene oxidation was observed. The styrene conversion was increased to $80.1 \%$ and the benzaldehyde selectivity was $86.5 \%$ (Table 1, entry 6). On further increasing both HAC and $p$-TsOH to $100 \mathrm{mg}$ and $0.58 \mathrm{mmol}$, respectively, the styrene conversion increased to $>99 \%$, and the selectivity for benzaldehyde decreased to $53.2 \%$. These results indicated that the appropriate ratio and amount of $\mathrm{HAC}$ and $p$-TsOH were an important factor for obtaining high activity and selectivity in styrene oxidation.

For the $10 \mathrm{mg} \mathrm{HAC}$ and $0.058 \mathrm{mmol} p$-TsOH system, when increasing the reaction temperature from 40 to $80{ }^{\circ} \mathrm{C}$, the styrene conversion increased remarkably from $13.6 \%$ to $68.2 \%$. The benzaldehyde selectivity decreased from $87 \%$ to $71.7 \%$, and the corresponding benzoic acid selectivity was gradually increased. Thus, increasing the reaction temperature can improve the oxidation ability of the $p$ - TsOH/HAC/ $\mathrm{H}_{2} \mathrm{O}_{2}$ system. At $60{ }^{\circ} \mathrm{C}$, when increasing the molar ratios of $\mathrm{H}_{2} \mathrm{O}_{2}$ /styrene from 2.5 to 3.5 , the styrene conversion increased from $14.1 \%$ to $35.3 \%$. With further increasing of the molar ratio to 4.5 , the styrene conversion was almost unchanged (Table1, entries 2 and 13). This indicated that when the amount of catalyst and reaction temperature were fixed, excess $\mathrm{H}_{2} \mathrm{O}_{2}$ could not be effectively activated. Moreover, after the reaction, the HAC was filtrated, washed, dried, and used again. The styrene conversion and benzaldehyde selectivity with the $\mathrm{HAC}$ used $/ p-\mathrm{TsOH} / \mathrm{H}_{2} \mathrm{O}_{2}$ were almost equal to those of fresh HAC (Table 1, entries 13 and 14).

\subsection{Effect of the surface groups of the $A C$}

To explore the effect of the carbon surface chemistry on the oxidation reaction, the styrene oxidation was catalyzed by a high temperature treated $\mathrm{HAC}\left(\mathrm{HAC}_{\mathrm{H} 2}\right.$ and $\left.\mathrm{HAC}_{\mathrm{N} 2}\right)$ or untreated $\mathrm{HAC}$, and $p$-TsOH. The results are shown in Fig. 1. When using $50 \mathrm{mg} \mathrm{HAC}$ as catalyst, the conversion of styrene was very low (8.5\%, $10 \mathrm{~h})$. Similarly, with the heat-treated HAC (50 mg) as catalyst, the conversion of styrene was still low. After $10 \mathrm{~h}$ of reaction, the conversion of styrene and the selectivity for benzaldehyde were $4 \%$ and $95 \%$ for $\mathrm{HAC}_{\mathrm{H} 2}$ and $5 \%$ and $86 \%$ for $\mathrm{HAC}_{\mathrm{N} 2}$, respectively.

When using only $0.29 \mathrm{mmol} p$-TsOH as catalyst, the conver-

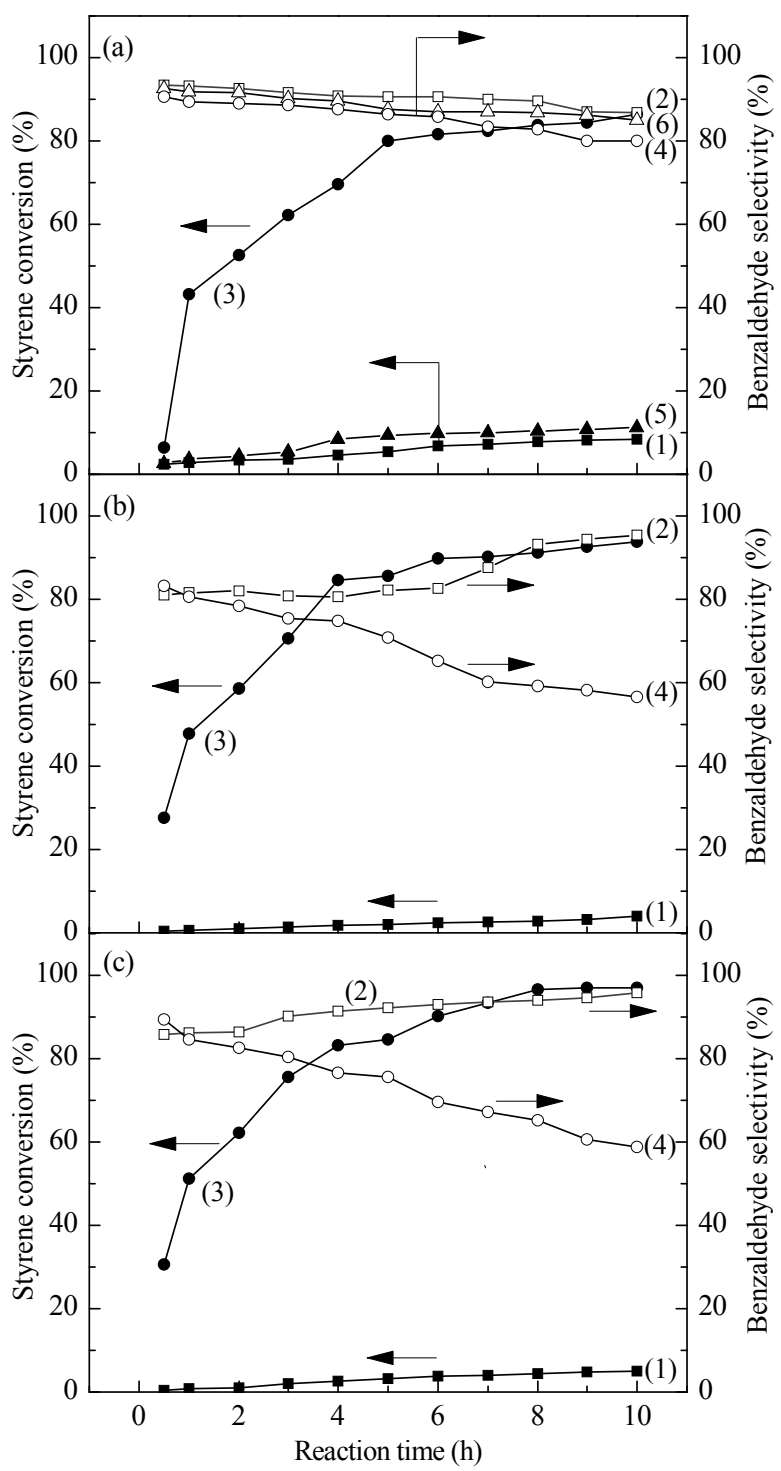

Fig. 1. Oxidation of styrene to benzaldehyde using different catalysts. (a) $\mathrm{HAC} / p$ - $\mathrm{TsOH}$; (b) $\mathrm{HAC}_{\mathrm{H} 2} / p$ - $\mathrm{TsOH}$; (c) $\mathrm{HAC}_{\mathrm{N} 2} / p$-TsOH. (1) Styrene conversion with AC; (2) Benzaldehyde selectivity with AC; (3) Styrene conversion with $\mathrm{AC} / p$-TsOH; (4) Benzaldehyde selectivity with $\mathrm{AC} / p$-TsOH; (5) Styrene conversion with $p$-TsOH; (6) Benzaldehyde selectivity with $p$-TsOH. Reaction conditions: AC $50 \mathrm{mg}, p$-TsOH 0.29 mmol, styrene $5 \mathrm{mmol}$, acetonitrile $5 \mathrm{~mL}, \mathrm{H}_{2} \mathrm{O}_{2}$ /styrene molar ratio 3.5, $60^{\circ} \mathrm{C}, 10 \mathrm{~h}$. 
sion of styrene also was very low (11\%, $10 \mathrm{~h}$ ) (Fig. 1(a)). With the simultaneous use of $p$-TsOH and heat-treated HAC as catalyst, compared with HAC (89\% styrene conversion and $80 \%$ benzaldehyde selectivity), the conversion of styrene was further increased to $94 \%$ for $\mathrm{HAC}_{\mathrm{H} 2}$ and $97 \%$ for $\mathrm{HAC}_{\mathrm{N} 2}$. The corresponding selectivity for benzaldehyde decreased to $57 \%$ and $61 \%$ after $10 \mathrm{~h}$ of reaction, respectively. More benzoic acid was observed, implying that styrene was over-oxidized.

The three different $\mathrm{AC}\left(\mathrm{HAC}, \mathrm{HAC}_{\mathrm{H}}\right.$, and $\left.\mathrm{HAC}_{\mathrm{N} 2}\right)$ were characterized to investigate the surface and structure. For HAC and heat-treated HAC, the XRD patterns exhibited similar diffraction peaks at $2 \theta=10^{\circ}-60^{\circ}$. All the three sample frameworks were amorphous (Fig. 2(a)) [30]. The FT-IR spectra of HAC and heat-treated HAC are shown in Fig. 2(b). For the HAC sample, it displayed $\mathrm{O}-\mathrm{H}$ stretches $\left(3654 \mathrm{~cm}^{-1}\right), \mathrm{C}=0$ stretches $(1708$ $\left.\mathrm{cm}^{-1}\right), \quad \mathrm{C}=\mathrm{C}$ stretches $\left(1594 \mathrm{~cm}^{-1}\right)$, and $\mathrm{C}-0$ stretches (1000-1200 $\mathrm{cm}^{-1}$ ) [31,32]. After HAC was heat-treated in $\mathrm{H}_{2} / \mathrm{Ar}$ or $\mathrm{N}_{2}$ at $800{ }^{\circ} \mathrm{C}$, remarkable decrease of the bands at 3654 and $1000-1200 \mathrm{~cm}^{-1}$ were observed. The results indicated that the oxygen-containing groups on the carbon surface were decreased by the high temperature treatment of HAC, in agreement with literature reports [29,33]. The total acidity of the AC was obtained using a standard acid-base back titration [23]. The total acidity were $0.239 \mathrm{mmol} / \mathrm{g}$ for HAC, 0.087 $\mathrm{mmol} / \mathrm{g}$ for $\mathrm{HAC}_{\mathrm{H} 2}$, and $0.099 \mathrm{mmol} / \mathrm{g}$ for $\mathrm{HAC}_{\mathrm{N} 2}$. The decrease in the total acidity was attributed to the reduction of the oxygen-containing groups by the high temperature treatment of AC, which was consistent with the FT-IR results. The decrease in the amount of the oxygen-containing groups was very beneficial for the decomposition of $\mathrm{H}_{2} \mathrm{O}_{2}[29,33]$ and more $\cdot \mathrm{OH}$ radicals were formed, which in turn increased the styrene conversion, and reduced the corresponding selectivity for benzaldehyde for the $\mathrm{HAC}_{\mathrm{H} 2}$ or $\mathrm{HAC}_{\mathrm{N} 2}$ and $p$-TsOH systems.

The $\cdot \mathrm{OH}$ formed in the $\mathrm{H}_{2} \mathrm{O}_{2}$ system can be probed using a method described previously [34]. It is known that $\bullet \mathrm{OH}$ reacts with terephthalic acid (TA) in basic solution to generate $\mathrm{TAOH}$, which emits a unique fluorescence signal with its peak centered at $427 \mathrm{~nm}$. Figure 3 shows the comparison of the fluorescence intensity for different samples illumined for a fixed time (30 min) with pure $\mathrm{H}_{2} \mathrm{O}_{2}$ as the reference. It was obvious that the

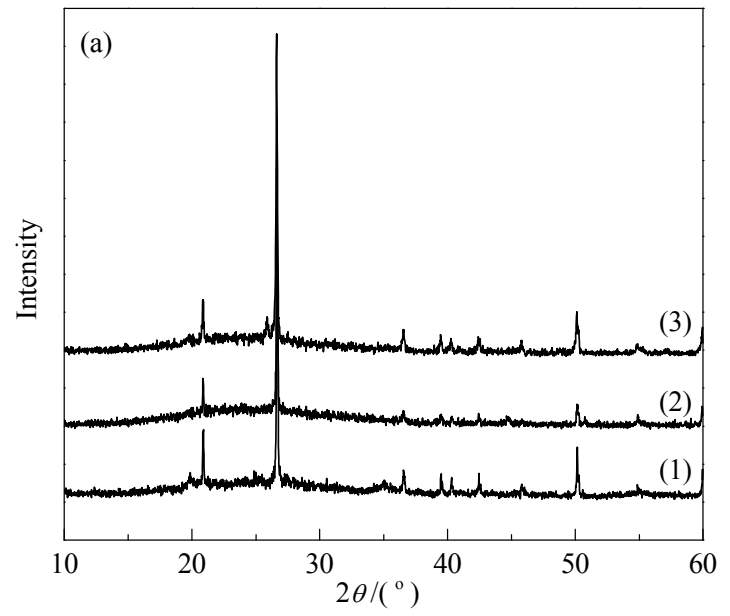

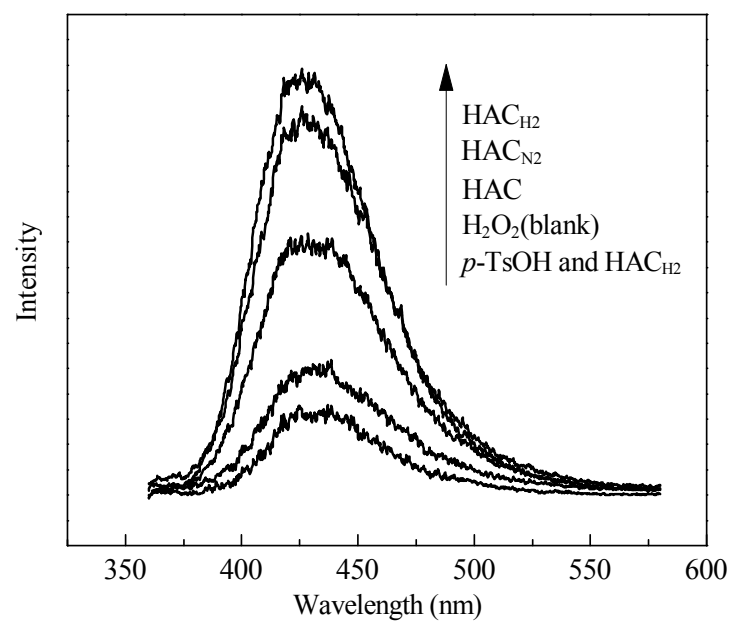

Fig. 3. Fluorescence spectra of TAOH formed by the reaction of TA with - $\mathrm{OH}$ radicals generated by different samples under visible light irradiation for $30 \mathrm{~min}$.

fluorescence intensity was proportional to the amount of produced hydroxyl radicals. The amount of $\bullet \mathrm{OH}$ produced on the heat-treated HAC was more than that of the $\cdot \mathrm{OH}$ produced on HAC. This also agreed with their catalytic activities for $\mathrm{H}_{2} \mathrm{O}_{2}$ decomposition and styrene conversion. For the $p$-TsOH and $\mathrm{HAC}_{\mathrm{H} 2}$ system, the formation of $\cdot \mathrm{OH}$ was inhibited, suggesting that the mechanism of $\mathrm{H}_{2} \mathrm{O}_{2}$ decomposition was changed in the presence of $p$-TsOH.

There were oxygen-containing groups (such as $-\mathrm{OH}$, $-\mathrm{COOH}$ ) on the surface of $\mathrm{HAC}$ and the $-\mathrm{SO}_{3} \mathrm{H}$ groups of $p$ - $\mathrm{TsOH}$ in the $p$-TsOH/HAC system. To determine which of the oxygen-containing groups or $-\mathrm{SO}_{3} \mathrm{H}$ plays a leading role, $\mathrm{HAC}$ was heated in concentrated $\mathrm{H}_{2} \mathrm{SO}_{4}$ to introduce sulfate acid groups $\left(-\mathrm{SO}_{3} \mathrm{H}\right)[15]$. This was labeled $\mathrm{HAC}-\mathrm{SO}_{3} \mathrm{H}$. After the sulfonation treatment of $\mathrm{HAC}$, hydrophilic groups $\left(-\mathrm{SO}_{3} \mathrm{H},-\mathrm{COOH},-\mathrm{OH}\right)$ coexist on the surface of the $\mathrm{HAC}-\mathrm{SO}_{3} \mathrm{H}$ sample [35]. With HAC-SO${ }_{3} \mathrm{H}$ as the catalyst, the conversion of styrene and selectivity for benzaldehyde were $64.8 \%$ and $80.6 \%$, respectively, which were significantly higher than those when using only HAC as the catalyst under the same reaction conditions. This

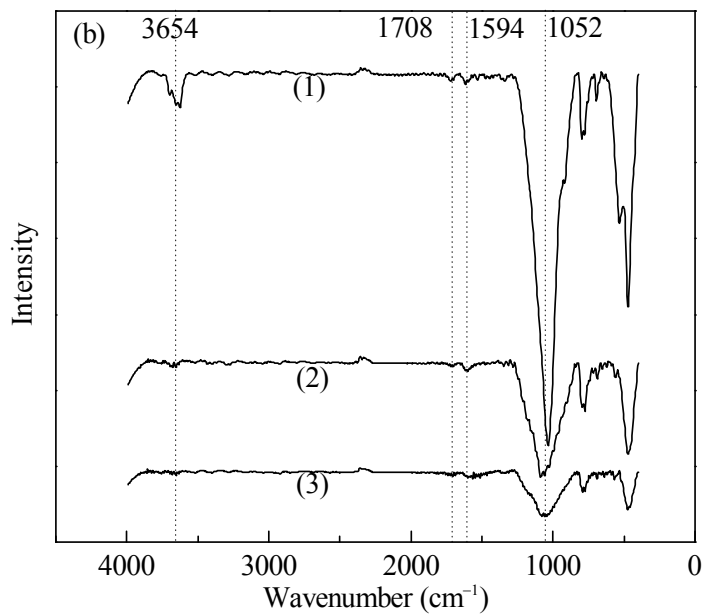

Fig. 2. XRD patterns (a) and FT-IR spectra (b) of $\mathrm{HAC}(1), \mathrm{HAC}_{\mathrm{H} 2}$ (2), and $\mathrm{HAC}_{\mathrm{N} 2}(3)$. 
showed that the $\mathrm{SO}_{3} \mathrm{H}$ group was much more effectively than the oxygen-containing groups for promoting the oxidation of styrene using $\mathrm{H}_{2} \mathrm{O}_{2}$ as oxidant.

\subsection{Amount of $\mathrm{H}_{2} \mathrm{O}_{2}$ in the $\mathrm{p}-\mathrm{Ts} \mathrm{OH} / \mathrm{HAC}$ system}

Both styrene oxidation and $\mathrm{H}_{2} \mathrm{O}_{2}$ decomposition proceed simultaneously in styrene oxidation process and the contribution to the gas volume was measured in the reaction solution. Figure 4 demonstrates the kinetic oxygen evolution curves with different $\mathrm{H}_{2} \mathrm{O}_{2}$ systems. When styrene, acetonitrile, and $\mathrm{H}_{2} \mathrm{O}_{2}$ were mixed and stirred at $60{ }^{\circ} \mathrm{C}$, a small amount of oxygen evolution was observed, which was attributed to $\mathrm{H}_{2} \mathrm{O}_{2}$ decomposition by the heating and stirring of the solution. An hour later, the reaction achieved equilibrium. When $0.29 \mathrm{mmol}$ of $p$-TsOH was added into the above mixture, no further decomposition of $\mathrm{H}_{2} \mathrm{O}_{2}$ was observed. Some $\mathrm{O}_{2}$ was produced by adding $50 \mathrm{mg} \mathrm{HAC}$ into the mixture of styrene, acetonitrile, and $\mathrm{H}_{2} \mathrm{O}_{2}$. AC acts as an initiator for the decomposition of $\mathrm{H}_{2} \mathrm{O}_{2}$, yielding free radical species such as $\cdot \mathrm{OH}$ in solution $[11,12,29,33]$. These results are in agreement with the fluorescence results. Given the poor catalytic activity observed when using only $\mathrm{HAC}$ as catalyst, the free radicals from the HAC reaction with $\mathrm{H}_{2} \mathrm{O}_{2}$ cannot effectively oxidize styrene. When $50 \mathrm{mg}$ of HAC and $0.29 \mathrm{mmol} p$-TsOH were simultaneously added into the mixture of styrene, acetonitrile, and $\mathrm{H}_{2} \mathrm{O}_{2}$, compared to the addition of only $50 \mathrm{mg}$ of $\mathrm{HAC}$, the amount of $\mathrm{O}_{2}$ evolved slightly decreased, but was higher than that using only $0.29 \mathrm{mmol}$ $p$-TsOH. Combining with the data of styrene oxidation, the free radicals species formed by $\mathrm{HAC}$ was more conducive to the styrene oxidation through promoting the $p-\mathrm{TsOH} / \mathrm{H}_{2} \mathrm{O}_{2}$ system.

For the system of $50 \mathrm{mg} \mathrm{HAC}$ and $0.29 \mathrm{mmol} p$-TsOH, the amount of $\mathrm{H}_{2} \mathrm{O}_{2}$ decomposition calculated by the volume of generated $\mathrm{O}_{2}$ and the amount of residual $\mathrm{H}_{2} \mathrm{O}_{2}$ measured by the iodometric method after reaction are shown in Table 2. The

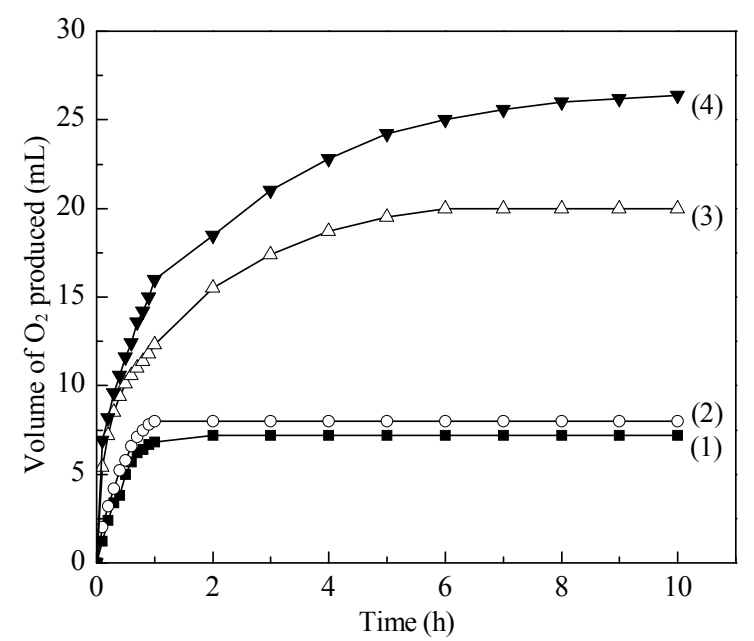

Fig. 4. Kinetics curves of $\mathrm{O}_{2}$ produced by the decomposition of $\mathrm{H}_{2} \mathrm{O}_{2}$ in the different reaction systems. (1) Mixture of acetonitrile, styrene, and $\mathrm{H}_{2} \mathrm{O}_{2}$; (2) Acetonitrile, styrene, $p$ - $\mathrm{TsOH}$, and $\mathrm{H}_{2} \mathrm{O}_{2}$; (3) Acetonitrile, styrene, $p$-TsOH, $\mathrm{HAC}$, and $\mathrm{H}_{2} \mathrm{O}_{2}$; (4) Acetonitrile, styrene, $\mathrm{HAC}$, and $\mathrm{H}_{2} \mathrm{O}_{2}$. Reaction conditions: HAC $50 \mathrm{mg}, p$-TsOH $0.29 \mathrm{mmol}$, styrene $5 \mathrm{mmol}$, acetonitrile $5 \mathrm{~mL}$, molar ratio of $\mathrm{H}_{2} \mathrm{O}_{2} /$ styrene $3.5,60^{\circ} \mathrm{C}$.
Table 2

Amounts of $\mathrm{H}_{2} \mathrm{O}_{2}$ in different catalyst systems.

\begin{tabular}{lccc}
\hline $\begin{array}{l}\text { Catalyst } \\
\text { system }\end{array}$ & $\begin{array}{c}\mathrm{H}_{2} \mathrm{O}_{2} \text { decomposition } \\
\text { HAC/ } p \text {-TsOH }\end{array}$ & $\begin{array}{c}\text { Residual } \mathrm{H}_{2} \mathrm{O}_{2} \\
(\%)\end{array}$ & $\begin{array}{c}\text { Reactive } \mathrm{H}_{2} \mathrm{O}_{2} \\
(\%)\end{array}$ \\
$\mathrm{HAC}$ & 8.4 & 7.9 & 79.9 \\
$\mathrm{HAC}_{\mathrm{N} 2} / p$ - $\mathrm{TsOH}$ & 10.8 & 20.7 & 65.8 \\
$\mathrm{HAC}_{\mathrm{N} 2}$ & 7.1 & 6.8 & 81.6 \\
$\mathrm{HAC}_{\mathrm{H} 2} / p$ - $\mathrm{TsOH}$ & 14.5 & 22.4 & 63.1 \\
$\mathrm{HAC}_{\mathrm{H} 2}$ & 6.2 & 4 & 89.8 \\
\hline
\end{tabular}

Reaction conditions: $p$-TsOH $0.29 \mathrm{mmol}, \mathrm{HAC}\left(\mathrm{HAC}_{\mathrm{H} 2}\right.$, or $\left.\mathrm{HAC}_{\mathrm{N} 2}\right) 50 \mathrm{mg}$, acetonitrile $5 \mathrm{~mL}$, styrene $5 \mathrm{mmol}, \mathrm{H}_{2} \mathrm{O}_{2}$ /styrene molar ratio $3.5,60^{\circ} \mathrm{C}$, $10 \mathrm{~h}$.

amount of $\mathrm{H}_{2} \mathrm{O}_{2}$ decomposition in the $p$-TsOH/HAC system was less than that of the with only HAC system. This may be due to the presence of $p$-TsOH, which acidified the reaction mixture and partially inhibited the decomposition of $\mathrm{H}_{2} \mathrm{O}_{2}$. The amount of residual $\mathrm{H}_{2} \mathrm{O}_{2}$ in the $p$-TsOH/HAC system also was less than that in the $\mathrm{HAC}$ system. Therefore, more $\mathrm{H}_{2} \mathrm{O}_{2}$ participated in the oxidation of styrene in the $p-\mathrm{TsOH} / \mathrm{HAC} / \mathrm{H}_{2} \mathrm{O}_{2}$ system.

Compared with $\mathrm{HAC}$ and heat-treated $\mathrm{HAC}$, the latter showed better activity for the decomposition of $\mathrm{H}_{2} \mathrm{O}_{2}$ (Table 2). The amounts of $\mathrm{H}_{2} \mathrm{O}_{2}$ decomposition increased in the following order: $\mathrm{HAC}_{\mathrm{H} 2}>\mathrm{HAC}_{\mathrm{N} 2}>\mathrm{HAC}$. The better decomposition of $\mathrm{H}_{2} \mathrm{O}_{2}$ was attributed to the presence of a higher amount of basic surface groups (formed by the high temperature treatment of AC) that can interact with $\mathrm{H}_{2} \mathrm{O}_{2}$ to donate one electron, which resulted in the formation of $\cdot \mathrm{OH}$ and further formation of $\mathrm{O}_{2}$ $[11,12,24]$. The increased $\cdot \mathrm{OH}$ formed by the heat-treated HAC facilitated styrene conversion, but decreased the selectivity for benzaldehyde with reaction time.

\subsection{Effect of acidity and free radical scavenger}

Reaction mechanisms in the liquid phase are generally more complex, and may involve a combination of homogeneous and heterogeneous reaction steps. On the basis of previously reported mechanisms on the catalytic application of acids in the oxidation of organic compounds using $\mathrm{H}_{2} \mathrm{O}_{2}$ [17,36-38], one explanation is that $p$ - $\mathrm{TsOH}$ acts as a protic acid, which polarizes the $\mathrm{O}-\mathrm{O}$ bond in $\mathrm{H}_{2} \mathrm{O}_{2}$ through hydrogen bonding to produce the reactive oxygen transfer agent. Another possible explanation is the in situ formation of peroxysulfonic acid by the reaction of $p$-TsOH with $\mathrm{H}_{2} \mathrm{O}_{2}$, followed by oxygen transfer to the organic compound.

To clarify the effect of the acidity of $p$-TsOH on the $p$-TsOH/HAC system, when using the same molar amounts of $\mathrm{HCl}$ or $\mathrm{H}_{2} \mathrm{SO}_{4}$ to replace $p$ - $\mathrm{TsOH}$, the styrene conversion and selectivity for benzaldehyde were $6 \%$ and $89 \%$ for $\mathrm{HCl}$, and $9 \%$ and $90 \%$ for $\mathrm{H}_{2} \mathrm{SO}_{4}$, respectively. This suggested that the acidity of the $p$-TsOH/HAC system was not an important factor for the oxidation of styrene.

Tertiary butanol, a free radical scavenger, was added into the reactant. With only $p$-TsOH as the catalyst, styrene oxidation gave: in the absence of tertiary butanol, 11\% styrene conversion and $82 \%$ selectivity for benzaldehyde, and in the presence of tertiary butanol, $13 \%$ styrene conversion and $87 \%$ se- 


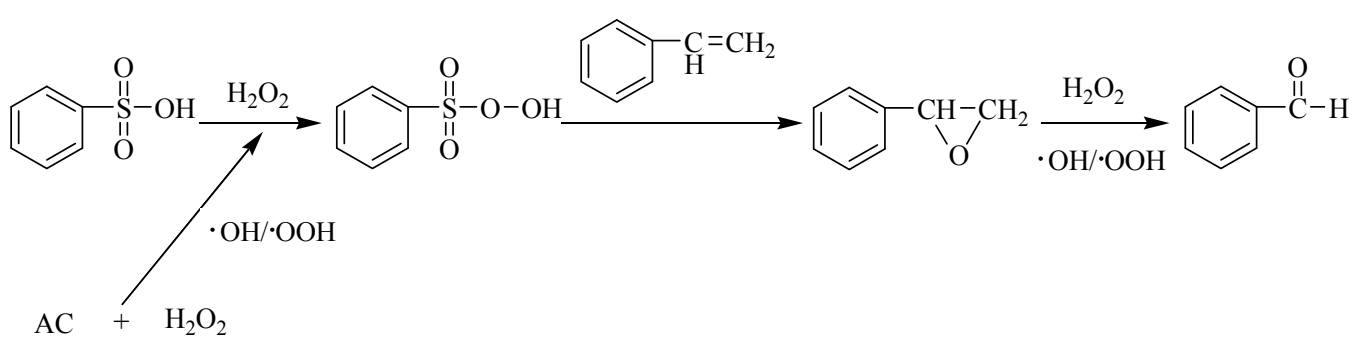

Scheme 1. Oxidation of styrene in the $p-\mathrm{Ts} \mathrm{OH} / \mathrm{HAC} / \mathrm{H}_{2} \mathrm{O}_{2}$ system.

lectivity for benzaldehyde. The oxidation of styrene was not affected by the radical scavenger, implying that the reaction is a non-radical process. Thus, styrene oxidation with only $p$-TsOH is possible due to the in situ formation of peroxysulfonic acid as a powerful oxidizing reagent $[12,16]$, which reacts with styrene to give the intermediate epoxystyrene. Finally, the oxidation of epoxystyrene yields benzaldehyde.

With both $p$-TsOH and HAC as catalyst, the oxidation reaction gave: in the absence of tertiary butanol, $52 \%$ styrene conversion and $75 \%$ selectivity for benzaldehyde, and in the presence of tertiary butanol, $43 \%$ styrene conversion and $72 \%$ selectivity for benzaldehyde. The oxidation of styrene was slightly influenced by the radical scavenger. This implied that the addition of $\mathrm{HAC}$ into the $p$ - $\mathrm{TsOH} / \mathrm{H}_{2} \mathrm{O}_{2}$ system promoted the formation of peroxysulfonic acid and accelerated the oxidation of epoxystyrene to benzaldehyde (Scheme 1).

\section{Conclusions}

Either $p$-TsOH with $-\mathrm{SO}_{3} \mathrm{H}$ groups or $\mathrm{HAC}$ with large amounts of oxygen-containing groups can activate $\mathrm{H}_{2} \mathrm{O}_{2}$ to oxidize styrene to benzaldehyde. The $-\mathrm{SO}_{3} \mathrm{H}$ groups were more effective than the oxygen-containing groups. However, both these two samples showed very low activity for styrene oxidation. There was a strong promotion effect by HAC on the $p$ - $\mathrm{TsOH} / \mathrm{H}_{2} \mathrm{O}_{2}$ system. With the simultaneous use of $p$-TsOH and $\mathrm{HAC}$, the styrene conversion increased to eight times higher than that using either $p$-TsOH or HAC, while the selectivity for benzaldehyde only showed a modest decrease. The promotion mechanism of $\mathrm{HAC}$ to the $p$ - $\mathrm{TsOH} / \mathrm{H}_{2} \mathrm{O}_{2}$ system was attributed to the interaction of the radical reaction $\left(\mathrm{HAC} / \mathrm{H}_{2} \mathrm{O}_{2}\right)$ and non-radical process $\left(p\right.$ - $\left.\mathrm{TsOH} / \mathrm{H}_{2} \mathrm{O}_{2}\right)$.

\section{References}

[1] Thao N T, Trung H H. Catal Commun, 2014, 45: 153

[2] Dhakshinamoorthy A, Primo A, Concepcion P, Alvaro M, Garcia H. Chem Eur J, 2013, 19: 7547

[3] Nemanashi M, Meijboom R. Catal Lett, 2013, 143: 324

[4] Sharma S, Sinha S, Chand S. Ind Eng Chem Res, 2012, 51: 8806

[5] Adam F, Iqbal A. Chem Eng J, 2010, 160: 742

[6] Patel A, Patel K. Inorg Chim Acta, 2014, 419: 130

[7] Tong J H, Cai X D, Wang H Y, Zhang Q P. Mater Res Bull, 2014, 55 : 205

[8] Jury F A, Polaert I, Pierella L B, Estel L. Catal Commun, 2014, 46: 6

[9] Zhuang J Q, Ma D, Yan Z M, Liu X M, Han X W, Bao X H, Zhang Y H, Guo X W, Wang X S. Appl Catal A, 2004, 258: 1

[10] Saux C, Pierella L B. Appl Catal A, 2011, 400: 117

[11] Navalon S, Dhakshinamoorthy A, Alvaro M, Garcia H. ChemSusChem, 2011, 4: 1712

[12] Maggi R, Piscopo C G, Sartori G, Storaro L, Moretti E. Appl Catal A, 2012, 411-412: 146

[13] Zhang B H, Ren J W, Liu X H, Guo Y, Guo Y L, Lu G Z, Wang Y Q. Catal Commun, 2010, 11: 629

[14] Saikia L, Satyartthi J K, Srinivas D, Ratnasamy P. J Catal, 2007, 252: 148

[15] Mo X H, López D E, Suwannakarn K, Liu Y J, Lotero E, Goodwin J G Jr, Lu C Q.J Catal, 2008, 254: 332

[16] Zhou L P, Dong B B, Tang S, Ma H, Chen C, Yang X M, Xu J. J Energy Chem, 2013, 22: 659

[17] Usui Y, Sato K, Tanaka M. Angew Chem Int Ed, 2003, 42: 5623

[18] de Jong M C, Feijt R, Zondervan E, Nijhuis T A, de Haan A B. Appl Catal A, 2009, 365: 141

[19] Mun S P, Jang J P. J Ind Eng Chem, 2009, 15: 743

[20] Hassanabadi A.J Chem Res, 2013, 37: 152

[21] Anuradha V, Srinivas P V, Aparna P, Rao J M. Tetrahedron Lett, 2006, 47: 4933

[22] Rostami A, Hassanina F, Ghorbani-Choghamarani A, Saadati S.

\section{Graphical Abstract}

Chin. J. Catal., 2015, 36: 721-727 doi: 10.1016/S1872-2067(14)60314-4

Oxidation of styrene to benzaldehyde by $p$-toluenesulfonic acid using hydrogen peroxide in the presence of activated carbon

Nianzhe Li, Yuan Gao, Xinxin Zhang, Zhanjun Yu, Lei Shi, Qi Sun* Liaoning Normal University

In the $p$-toluenesulfonic acid/activated carbon $/ \mathrm{H}_{2} \mathrm{O}_{2}$ system, there is an interaction of a radical reaction $\left(\mathrm{HAC} / \mathrm{H}_{2} \mathrm{O}_{2}\right)$ and non-radical process $\left(p-\mathrm{TsOH} / \mathrm{H}_{2} \mathrm{O}_{2}\right)$ for the oxidation of styrene to benzaldehyde.

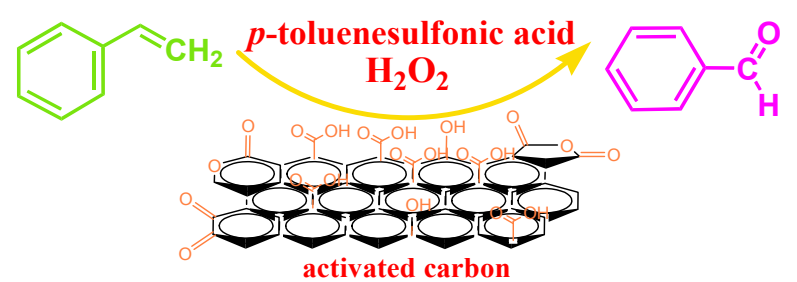


Phosphorus Sulfur Silicon Related Elements, 2013, 188: 833

[23] Boehm H P. Carbon, 1994, 32: 759

[24] Ramirez J H, Costa C A, Madeira L M, Mata G, Vicente M A, Rojas-Cervantes M L, López-Peinado A J, Martín-Aranda R M. Appl Catal B, 2007, 71: 44

[25] Oliveira L C A, Sillva C N, Yoshida M I, Lago R M. Carbon, 2004, 42: 2279

[26] Santos V P, Pereira M F R, Faria P C C, Órfão J J M. J Hazard Mater, 2009, 162: 736

[27] Lücking F, Köser H, Jank M, Ritter A. Water Res, 1998, 32: 2607

[28] Georgi A, Kopinke F D. Appl Catal B, 2005, 58: 9

[29] Rey A, Zazo J A, Casas J A, Bahamonde A, Rodriguez J J. Appl Catal A, 2011, 402: 146
[30] Dandekar A, Baker R T K, Vannice M A. Carbon, 1998, 36: 1821

[31] Shin S, Jang J, Yoon S H, Mochida I. Carbon, 1997, 35: 1739

[32] Figueiredo J L, Pereira M F R, Freitas M M A, Órfão J J M. Carbon, 1999, 37: 1379

[33] Khalil L B, Girgis B S, Tawfik T A M. J Chem Technol Biotechnol, 2001,76: 1132

[34] Ishibashi K, Fujishima A, Watanabe T, Hashimoto K. Elecochem Commun, 2000, 2: 207

[35] Chang B B, Fu J, Tian Y L, Dong X P. J Phys Chem C, 2013, 117: 6252

[36] van Vliet M C A, Arends I W C E, Sheldon R A. Synlett, 2001, 2: 248

[37] Wahlen J, De Vos D E, Jacobs P A. Org Lett, 2003, 5: 1777

[38] Shaabani A, Rezayan A H. Catal Commun, 2007, 8: 1112

\title{
对甲苯磺酸/活性炭/双氧水体系选择氧化苯乙烯生成苯甲醛
}

\author{
李念哲, 高 远, 张欣欣, 玉占君, 石 雷, 孙 琪 ${ }^{*}$ \\ 辽宁师范大学化学化工学院功能材料化学研究所, 辽宁大连116029
}

摘要: 以双氧水为氧化剂, 研究了对甲苯磺酸和活性炭体系选择氧化苯乙烯生成苯甲醛反应性能。考察了反应时间、温度、催化 剂用量、苯乙烯和双氧水摩尔比等对苯乙烯选择氧化性能的影响. 结果表明, 对甲苯磺酸和活性炭的用量和用量比是一个重要因 素, 但对甲苯磺酸的酸性对氧化反应活性影响不大. 对甲苯磺酸和双氧水相互作用, 经非自由基过程氧化苯乙烯. 通过分解双氧 水产生氢氧自由基, 活性炭显著提高对甲苯磺酸和双氧水体系氧化苯乙烯活性. 在惰性或还原气氛中高温处理活性炭能降低其 表面含氧基团数量, 增加碱性, 有效分解双氧水, 产生相对较多的 $\mathrm{OH}$ 自由基. 与未处理的活性炭相比, 高温处理的活性炭进一步 提高了对甲苯磺酸和双氧水体系氧化苯乙烯活性, 但降低了苯甲醛选择性. 经磺化, 在活性炭表面引入的 $-\mathrm{SO}_{3} \mathrm{H}$ 基团比含氧基团 $(-\mathrm{OH},-\mathrm{COOH})$ 更有效与双氧水作用氧化苯乙烯.

关键词: 苯乙烯; 双氧水; 对甲苯磺酸; 活性炭; 氧化

收稿日期: 2014-12-25. 接受日期: 2015-01-30. 出版日期: 2015-05-20.

*通讯联系人. 电话: (0411)82159069; 传真: (0411)82156858; 电子信箱: sunqils@163.com

基金来源：国家自然科学基金(21173110).

本文的英文电子版由Elsevier出版社在ScienceDirect上出版(http://www.sciencedirect.com/science/journal/18722067). 